\title{
The (De)Politicisation of Work - An Inquiry into the Political Function of Work
}

A (des)politização do trabalho - Um inquérito à função política do trabalho

La (dé)politisation du travail - Une enquête sur la fonction politique du travail

\section{Helena Lopes}

\section{(2) OpenEdition}

\section{Journals}

Electronic version

URL: http://journals.openedition.org/rccs/9276

DOI: $10.4000 /$ rccs. 9276

ISSN: 2182-7435

Publisher

Centro de Estudos Sociais da Universidade de Coimbra

Printed version

Date of publication: 1 September 2019

Number of pages: 149-170

ISSN: 0254-1106

\section{Electronic reference}

Helena Lopes, «The (De)Politicisation of Work - An Inquiry into the Political Function of Work », Revista Crítica de Ciências Sociais [Online], 119 | 2019, Online since 06 August 2019, connection on 08 August 2019. URL : http://journals.openedition.org/rccs/9276 ; DOI : 10.4000/rccs.9276 


\section{HELENA LOPES}

\section{The (De)Politicisation of Work - An Inquiry into the Political Function of Work*}

The paper revisits the debate on the political function of work, defined as the contribution of work to the production and transformation of social relations, in both conceptual and empirical terms. It begins by briefly recalling the terms of the debate about the emancipatory potential of work as seen by Karl Marx and Hannah Arendt, and then proceeds to argue, contra Arendt, that since work is a collective and cooperative activity, it is not a-political. The major contribution of the paper consists of discussing the issue by critically considering the literature on both economic theories of the firm and labour economics, two strands of literature usually kept apart. We regard the quantification and individualisation trends that characterise the contemporary world of work as a de-politicisation process, one linked to the (mainstream) agency theory of the firm which legitimises financialisation. We conclude by outlining a way in which to re-politicise work and the firm.

Keywords: business management; politicisation; social relations; wage; work.

Une société se juge au sort qu'elle réserve au travail SIMONE WeIL

\section{Introduction}

The debate about the political function of work opened with Karl Marx's claim that the consciousness-raising capacity of wage labour would result in emancipation through collective action. Hannah Arendt (1958) denied such potential, contending that work/labour is an essentially instrumental, and thus an a-political, activity. Marx's and Arendt's claims were based on quite divergent conceptions of the activity of work. Whereas the type of

\footnotetext{
"A first version of this paper was presented as a keynote at the First Annual Meeting of the Portuguese Association of Political Economy under the title "A Substantive Conception of Work and the Firm - Institutional Implications". Although the issue addressed in the present paper is different, its elaboration rests on the arguments previously developed.
} 
work Marx had in mind was craft work, which is meaningful and exhibits individuality, Arendt was very influenced by the Tayloristic modes of work organisation which, she argued, makes no room for individuality and identity. Thus, Arendt and other critical theorists expressly dismissed the idea that work can have any emancipatory potential since it would not allow for any type of consciousness. Our discussion of the political function of work is concentrated on seeing it as the contribution of work to the production and transformation of social relations (Cukier, 2017).

Our argument proceeds as follows: we begin by briefly recalling the terms of the debate about the emancipatory potential of work. We emphasise that the conceptual discussion is closely connected with the forms that work content and work organisation have taken historically. The advent of Taylorism was accompanied by a neutralisation of the concept of work and the dismantling in social philosophy of the emancipatory status of the nineteenth-century concept of work (Honneth, 1982) (Section One).

Section Two argues - contra Arendt and following, inter alia, Cukier (2017), Lopes (2016a), Fischbach (2015) and Dejours (2009) - that work, namely wage work, is not a-political and solely instrumental because it always involves a social, collective dimension. Production in firms is always a collective endeavour, which requires workers to cooperate, i.e. to consent to doing their part of the collective venture. Explaining this consent requires breaking with the view that regards behaviour at work as driven exclusively by instrumental incentives and with Arendt's view that considers work/labour as activities in which workers are undifferentiated bodies. We explain workers' cooperation by the behavioural norms that emerge from the interpersonal interactions into which they enter to perform their work. These behavioural norms are generated by sympathy, a human capacity insightfully elaborated upon by Adam Smith (2017 [1759]). The extent to which sympathy is promoted versus undermined by a given type of work organisation is assigned a critical role in our analysis of the political function of work.

In our view, discussing the political function of work demands that the firm be included in the analysis, something rarely done in economics, where the literature on the firm is maintained separate from labour economics. In fact, mainstream labour economics is centred on the analysis of the labour market and the activity of work is only addresses indirectly, in personnel economics and behavioural agency models. Additionally, since one cannot think about work without considering the forms it takes empirically, and since it is firms that determine such forms, it is fitting and appropriate to consider the modes that firm governance take, and what prompts such modes. Accordingly, Section Three focuses on the agency theory of the firm, a theory 
that presently exerts powerful influence on how firms are governed and the forms that work takes. In particular, agency theory denies the political nature of firms (Singer, 2019).

Section Four examines the key trends that characterise the contemporary world of work, namely the individualisation and quantification processes. It is argued that the latter epitomise a powerful de-politicisation of work. The individualisation, quantification and ultimately de-politicisation of work is generated by the "government of work by numbers" (Supiot, 2015), a set of management practices that now pervades all types of work organisations. We argue that these practices lead to the undermining of sympathy/solidarity in work organisations and to the promotion of a homo economicus type of behaviour, which explains the workers' lack of resistance and disposition for collective action. Work is not a-political because workers' individuality is not recognised, as professed by Arendt; it is de-politicised because it leads workers to focus on their individuality.

Section Five outlines a way to re-politicise work and the firm, namely through having workers participate in decision-making by generalizing the codetermination mode of firm governance. The last section offers concluding statements.

\section{The Debate about the Emancipatory Potential of Work}

The richness of Marx's conception of work is worthy of particular note. Firstly, following Hegel, Marx views work as one constitutive aspect of self-consciousness; through work individuals actualise their cognitive capabilities and engage in a process of intellectual self-development (Honneth, 1982). Marx sees work primarily as an active processing of nature, specific to human beings, which, along with being a factor of production, also generates a process of personal development. The capitalist organisation of labour undermines this meaning-dimension of work because it abstracts the worker from the objectifying character of the activity of work; this is why wage labour is alienating.

Secondly, world history is defined as the self-recreation and self-emancipation of society, a process in which work plays a major role. Marx apprehends this process through the concept of social labour which, on the one hand, designates the technical form of reproduction of human existence and related social organisation of work, and, on the other hand, is assigned with the function of a social learning process in which workers become aware of the fact that their capabilities and needs are constrained by the given social structure (ibidem). The process of social labour thus releases emancipatory perspectives that lay the ground for social revolution. 
Thus, contrary to many subsequent interpretations that see the social learning and emancipatory processes as ones (to be) primarily carried out by a social class - a supra-individual entity - Marx also assigns a subjective, individual emancipatory potential to work activity. It is this individual-level attribute of (contextually embedded) work that then translates into collective action. We would also like to highlight that Hegel pointed out that the potential for emancipation lies in the interdependency that characterises (the division of) work. It is because each individual is aware of his/her dependence on others' work for the satisfaction of his/her needs that he/she comes to transcend his/her individuality and espouses a universal attitude and associate reciprocity and mutual recognition norms (Fischbach, 2015).

Most twentieth-century social philosophers dismiss Marx's link between work and emancipation, assigning emancipation to other kinds of activity. Some go so far as to completely invert Marx's claims: workers no longer find in social labour the source of their potential power; instead, they see in it the power of the system and their own non-power (Gorz, in Fischbach, 2015). Since Hannah Arendt is one of the leading disputers of Marx's emancipation contentions, our discussion builds on a critical analysis of Arendt's conception of work in The Human Condition. Her basic argument is, following Aristotle, that in the activity of work/labour, there is neither an ethical dimension nor normative potential because no intersubjectivity is involved. Arendt (1958) distinguishes three forms of human activity: labour, work and action. Labour designates the repetitive and never-ending activities in which humans must engage to sustain the physiological requirements of life; individuals as labourers are bound to necessity. Work designates the activities through which humans transform the physical world in which they live. Finally, action refers to the activities involved in our living together; action is driven by the need to organise our living together and to have a good (in ethical terms) and meaningful life. In labour and in work, individuals relate only with nature and not with each other; work and labour are essentially non-social activities (this is why, given the purpose of the present paper, we hereafter only use the term "work"). Conversely, a key feature of action is that it does not take place in isolation from others.

Laboring is an activity in which man is neither together with the world nor with other people, but alone with his body, facing the naked necessity to keep himself alive. [...] It is indeed in the nature of laboring to bring men together in the form of a labor gang where any number of individuals 'labor together as if they were one'. [...] But this 'collective nature of labor', far from establishing a recognizable, identifiable, reality for each member of the labor gang, requires on the contrary the actual loss of 
all awareness of individuality and identity. [...] The sociability arising out of [labor] rests not on equality but on sameness. (Arendt, 1958: 212-213)

In the realm of labour and work, human beings are tied to materiality and fabricate 'the man-made-world' in solitude. By contrast, emancipation is possible only through "action" (political activity in Arendt's theoretical framework), an activity that goes on directly between individuals without the intermediary of things, which enables individuals to disclose 'who' they are. Only through "action", i.e. through interacting with others through words and deeds, can individuals reveal their individuality and display their virtue and character. "Action refers specifically and exclusively to the activities involved in our living together; it excludes "everything merely necessary or useful', that is, labour and work" (Lopes, 2016a: 9). Arendt seems to consider work a-political because she views work as merely instrumental and, importantly, because she considers that although work is a collective venture, there is no cooperation as such in the activity of work. That is, working with others does not involve interpersonal interactions, the kind of interactions that engage workers' individuality and allow them to display their virtues and character.

Marx's conception of work was very much influenced by the constellation of work forms of his time: the coexistence of meaningful, self-regulated craft work with the atomised, industrial division of work. It is craft work that led him and Hegel to consider that work can be a process of constructive objectification, a consideration difficult to hold in the face of mass production which divided the complete work procedure into partial and atomised operations controlled by the rhythm of machines. For Honneth (1982), Arendt's conception of work is overly linked to the forms that work took during the historical stage of Taylorism.

\section{Acknowledging the Collective and Cooperative Character of Wage Work - Crucial Implications}

Arendt expressly states that work is an "antipolitical way of life" (Arendt, 1958: 212) because, as mentioned, she assumes that in work human beings do not relate as unique and distinct persons. For her, it is only through action that individuals can distinguish themselves as distinct beings; that is, only action makes people political beings. Her argument is entirely grounded on the fact that she sees the "collective nature of labor" as a purely technical matter, one taking place between unidentifiable, undifferentiated individuals, i.e. a process that does not involve cooperation. Indeed, cooperating means operating in common, participating in a collective productive endeavour, 
which implies pursuing a common goal. In fact, most productive activities require a high level of interdependence between workers; the workers must together develop a common understanding of the problems to be solved and how this can be done. Most importantly, cooperation implies committing to the behaviours agreed upon with the other members of the organisation, which entails giving up on one's possible desire to free-ride on cooperative partners.

Participating in a collective productive endeavour involves engaging in interpersonal interactions, i.e. workers interact as particular individuals. ${ }^{1}$ The collective and interpersonal dimensions of work are both discarded in mainstream economic models. Even in the models that introduce social and moral motives into utility functions, individuals are calculative rather than social and moral beings (Lopes, 2016b). For example, Dur et al. (2010) do call attention to the many benefits good relationships may yield to the firm and recognise that they may motivate workers more powerfully than pecuniary incentives; likewise, employees' effort and employer's benevolent treatment of workers are modelled as reciprocal gifts that, though costly, appear as possibly efficient strategies (Non, 2012). Nevertheless, these human dispositions are considered social preferences, which are introduced into the individualistic ontological apparatus of rational choice theory; however, the latter only recognises cognitive, not affective elements (Sugden, 2005), which are the elements activated in interpersonal human interactions that account for cooperative behaviour (see below). In the same vein, cooperation is not viewed as an outcome of continued social interactions; i.e. a collective endeavour, but instead as a residual kind of behaviour: "voluntary cooperation is defined as the difference between actual and privately optimal effort" (Non, 2012: 322). The decision to cooperate is taken separately by each worker depending on his/her preferences rather than emerging from the fact that workers are engaged in a collective productive venture. Instead, we consider that cooperation stems from social interactions and that, as argued by Hodgson (2013), cooperating cannot be accounted for by introducing ad-hoc preferences into individualistic utility functions.

\footnotetext{
${ }^{1}$ It must be noted that Marx (1867), like Arendt one century later, refers to cooperation as the mere juxtaposition of workers by capital; cooperation would thus involve no social interactions. Conversely, we argue that workers do interact as persons when working and do subjectively engage at work, as documented in studies on the psychodynamics of work, even when the engagement takes the negative form of withdrawal (Dejours, 2016, 2009). Of course, we acknowledge that cooperation is largely imposed by the firm, but our account of cooperation sees it as resulting from both bottom-up (making room for agency) and top-down (social structure) phenomena; institutions depend on individuals just as individuals are moulded by institutions.
} 
According to Adam Smith's concept of sympathy (The Theory of Moral Sentiments, 1759), the interpersonal relations into which individuals enter generate affective states that help emerge and sustain norms of cooperation. Our claim is that this also occurs when individuals work together, which means that workers do relate with each other as distinct, unique, moral individuals. Smith's basic psychological assumption is that individuals have a capacity to feel the experience of others imaginatively and so to share their pleasures and pains, this leads to a "correspondence of sentiments" between people. This correspondence of affective states is, in turn, the basis for judgments of approval or disapproval of both one's own actions and those of others. The whole process thus involves both cognitive (judgmental) and affective elements.

Sympathy, now most commonly referred to as empathy, has seen renewed interest among psychologists and neuroscientists since the 2000s. The ubiquitous reference to Adam Smith is striking; it is as though not much has been discovered about the psychological processes underlying empathy other than their neurological - mirror neurons - or neurobiological - oxitocyn - substrates (Rizzolatti and Craighero, 2005; Zak and Barraza, 2013, respectively). Collective action, i.e. behaviours that are performed with others to meet a goal or reach a desired outcome, and empathy are driven by the same physiologic drivers - this is why neuroscientists regard empathy as promoting cooperation (Zak and Barraza, 2013). Intersubjectivity is recognised as the ontological ground of the human condition (Gallese, 2008) and it is shown that individuals are often self-concerned and other-orientated at the same time (Bolino and Grant, 2016).

Adam Smith was right: sympathy does appear to be the basis for moral behaviour and cooperation; it accounts for why workers do not usually free-ride on others' efforts (which is, by contrast, the default behavioural assumption of mainstream economics). Workers, through the recurrent interactions they enter into while participating in collective production, tend to subscribe to the same behavioural norms (processes of affective dissonance and corresponding judgments of disapproval may, of course, lead to severe disruptive events and breaks in cooperation).

The abilities required to sustain cooperation, namely, making promises and fulfilling commitments, are assigned exclusively to (political) action by Arendt (and Aristotle). But once we recognise that work is permeated by cooperative behaviour, it follows that the processes Arendt assigns to the political sphere can also take place in workplaces. The exercise of virtue is the motive underlying action in Arendt's framework; virtue stems from humans' ability to see things not only from their own point of view but also 
from the perspective of those with whom they interact. This is what occurs when workers are embedded in a collective productive process, i.e. when they pursue a common goal. As pointed out by Zamagni (2018: 17-19), the etymology of common is cum-munis, as opposed to im-munis which means without obligations; the common refers to the existence of an interpersonal sphere that brings with it obligations towards others.

A work collective is a set of persons plus the rules they build together; a working rule is always also a rule about how to live together. For Dejours (2016), cooperation involves deontic activity, i.e. the production of obligations and ethical norms, and cooperation is at the core of the political function/potential of work. Deontic activity in work requires workers to speak about their work and to express and justify their point of view on work-related matters; it also requires them to listen to others' views and concerns. ${ }^{2}$ This is a deliberative activity, what is properly considered "action", or political activity, by Arendt.

\section{The Missing Link: The Conception of the Firm and Related Governance Form}

In order for work to be emancipatory, it must, on the one hand, allow for class consciousness, as claimed by Marx, or at least it must allow workers to be aware of their being part of a collective, and, on the other hand, workers must be able to display their individuality and identity, as claimed by Arendt. Only then can work fulfill a positive political function by empowering workers to strive collectively for more democracy and to produce flourishing social relations. Whether contemporary work offers such scope depends on how it is designed and controlled (this is examined in the next section), which depends, in turn, on the prevailing management/governance practices, since the latter determine the former.

The decades after the Second World War were characterised by Fordism, a period in which a social pact was established between trade-unions and employers according to which workers benefitted from productivity gains (Boyer, 2005). This was the so-called managerial period where managers enjoyed relatively high discretion in determining the purposes of firms, namely growth and productivity increases as much as making profit (Favereau, 2018). An implicit alliance between managers and workers (taken as consumers) was established through collective bargaining, which resulted

\footnotetext{
${ }^{2}$ Dejours understands that the world of work is also made of manifold rivalries that often produce injustice and suffering. Acknowledging cooperation and deontic activity at work does not mean overlooking the domination and coextensive perverse processes generated by the hierarchical institutional context in which workers operate.
} 
in the development of internal labour markets. Although the counterpart was that managers had full control over work-related decisions - workers were deprived of any decision-making latitude and autonomy - a sense of collective was preserved through the protection afforded by internal labour markets and through influential workers' collective representative bodies. Work was reduced to a quantified amount; a certain number of work hours was exchanged for a certain amount of money, which was bearable thanks to social and effective collective rights. The work per se (purpose, content, methods, schedule) that each worker had to perform was largely determined by managers, and this was subject to very little discussion.

This Fordist compromise was unilaterally revoked in the subsequent, present stage of financialisation (Boyer, 2005). Financialisation, in its macro-level facet, powerfully impacts industrial relations systems, hence greatly affecting the balance of power between employers and employees. But it is the financialisation process taking place at the firm level, a process theoretically grounded on and empirically furthered by the economic, mainstream, agency theory of the firm (Favereau, 2016), which in our view most impacts the emancipatory potential of work.

Agency theory's rationale was launched by Friedman (1970:32-33) and he claims: i) that managers are "the agents of the individuals who own the corporations", namely shareholders, ${ }^{3}$ and consequently ii) that the purpose of firms and managers is to "make as much money as possible", not to "render certain [social] services". Friedman insists that managers must promote the interests of shareholders only, which is to make "money profit", and that declaiming that firms should "provide employment, eliminate discrimination and avoid pollution" is "preaching pure and unadulterated socialism". He hence expressly contends that it is not in the nature of firms to be political or perform some political role.

Friedman's arguments were turned into an economic theory of the firm by Jensen and Meckling (1976) - agency theory - a theory taught to millions of students and executives in business schools around the world which became a powerful normative model (Goshal, 2005). Agency theory views the firm as a nexus of contracts rather than a social institution aimed at producing goods and services. In fact, for Jensen and Meckling (1976), the firm is a

\footnotetext{
${ }^{3}$ Friedman was making a critical mistake in assuming that shareholders own the firm. It is clear for legal scholars, in both common law and coded civil law, that shareholders only own their shares of the corporation, not the firm, which is an economic entity (deprived of legal status) that cannot be owned (Favereau, 2018; Robé, 2012). Remarkably, public opinion and most economists discard this crucial fact. Published in the New York Times given its significant impact and because it epitomised prevailing views at the time, Friedman's paper is a major reference in the academic literature of economics, management and corporate law.
} 
means for finding optimal capital structure through minimizing debt financing costs; they accordingly focus on the relationship between shareholders as principals and managers as agents. The firm is formally reduced to a cascade of principal-agent contracts and the question of its governance is reduced to investigating which incentives best align the interests of each worker with those of the (supposed) owners of the firm. In this view, shareholders bear the greatest investment risk since their revenues depend on what is left after the contracts with other input providers are honoured. To protect their investments, they are given control over governance, i.e. over the board of directors (management). The maximisation of share-value then became the final criterion of the good governance of firms, and an explicit alliance between shareholders and managers was de facto established since the 1980s (Favereau, 2018; Boyer, 2005).

The view of the firm progressively changed from that of a centre of production and employment to that of a centre for the management of an assets' portfolio, with huge consequences on its governance. In fact, agency theory became the dominant paradigm in corporate scholarship and corporate law in the 1990s (Armour, 2005): "both boardrooms and courts have taken the normative call for shareholder value maximisation increasingly at heart" (Bodie, 2012: 1033). In conformance with Friedman's rationale, the "shareholder primacy" governance model, grounded on the principal/shareholders-agent/managers relationship, eschews employees (Bodie, 2012) and, indeed, the productive organisation itself. The firm, a productive entity composed of collectives of work, is transformed into a set of financial assets. This view partly explains why we are now witnessing a regression to forms of work prior to wage work (e.g. Uber and other forms of digital platform work), leaving workers without the legal and social protections associated with their integration into the firm.

\section{The Contemporary World of Work: The Depoliticisation of Work}

The financialisation of firms, promoted or at least legitimated by agency theory, has far-reaching effects on firm governance and on work. Managers' scope of discretion is now much more limited than in the Fordist era their decisions are greatly constrained by the (short-term) financial returns imposed by institutional investors. Besides, the rationale that now underlies their remuneration - an incentive structure designed to make them create "value" for shareholders - brought about a radical break with the former implicit alliance between managers and workers; top executives earned 295 times more than a typical American worker's wage in 2013 as compared with the figure of 20 times more in 1965 (Davis and Mishel, 2014). 
Financial objectives are now given priority over any other, and the quantification of work, which did not begin with financialisation, extensively disseminated under financialisation.

The quantification of work process involves two phases: first, financial targets are translated into localised and quantified objectives for each operational level, each activity and each worker; second, what has been done at each operational level and in each activity is reported by workers and translated into financial values (Favereau, 2016). The set of practices that embodies this "governance of work by numbers" (Supiot, 2015) - namely, the quantification of work targets and of performance appraisals, the pecuniary incentive schemes, and systematic reporting - if particularly suited to the pursuit of shareholder value maximisation, came to pervade not only publicly listed and financialised firms but all types of work organisations, including public services (e.g. academia and health).

Governance by numbers focuses on the outcomes of work rather than the workers as persons, which contributes to eluding workers' individuality in the eyes of managers; this is no historical novelty. What is new is that, by being based on numbers, this kind of governance is supposed to be axiologically neutral when in fact, since it overlooks the subjective and collective experience of work, it is actually a highly axiological phenomenon. The process of work quantification, being intimately linked to that of the individualisation of work, amounts to dismiss, in practical management terms, the collective character of work. ${ }^{4}$

The other novelty lies in the fact that workers' individuality, though eluded, is now expressly and intensively mobilised (Lopes, 2016b). The individualisation of work is carried out not solely through practices like the setting of individualised (quantified) performance targets and individualised (quantified) appraisal systems but also through the creation of an illusionary autonomy. Indeed, being aware that workers' loyalty and cooperative spirit are more efficiently fostered by granting them greater decision-making scope than submitting them to technical prescriptions and control, managers now often involve workers in the setting of the objectives they are required to achieve and for which they are made accountable. Workers are also often free to decide on the means and methods to reach

\footnotetext{
${ }^{4}$ In truth, management practices are highly diversified; they intensely discriminate, in particular, between highly qualified "core" workers and low-qualified easily replaceable workers, as comprehensively shown by labour segmentation studies. Also, we do not deny that there are many firms that do acknowledge and duly compensate cooperation, but empirical evidence from sociological and critical management literature suggests that the quantification and individualisation trends are prevalent and tend to grow rather than disappear.
} 
these objectives. The latter no longer look like prescriptions imposed from outside; rather, the workers feel like acting "freely", driven by their own will and self-control, which makes them strive to give their best. In truth, this autonomy aims at getting them objectively accountable and subjectively involved, without affording them more choice and opportunities for self-direction. Most importantly, this false autonomy contributes to obscuring the workers' sense of collective, promoting instead a competitive spirit.

Thus, many workers today do not perform some task because they were instructed to do so but because it is required to reach their targets. This is not Taylorism any longer (though Tayloristic work has certainly not disappeared); instead, self-control became key to the functioning of work organisations. Governance by numbers aims at establishing a self-regulated order (Supiot, 2015). In accordance with the firm-as-nexus-of-contracts view, firms would be inhabited by self-sufficient, separated workers driven by selfish utility calculus and the fear of losing their jobs.

The quantification of the work process deeply affects the way work is experienced, with wide influence on workers' values and behaviours. Governance by numbers is shown to prompt calculative and competitive behaviours by transforming the workers' subjective perceptions of their work. For example, Alvehus and Spicer (2012) report that "billable hours" practices lead workers to understand their work as a kind of investment that should be manipulated so as to reap maximal benefits, sometimes at the expense of colleagues who are lower in the hierarchy. Instead of experiencing the quantification of their work as an oppressive form of control, workers come to see their work life as an investment which may pay dividends in the future. Many of them declare experiencing the tension between the feeling of being part of a collective and the pressure to participate in a competitive game which often compels them to behave selfishly (if not opportunistically; see Alvehus and Spicer, 2012) to meet their quantified targets. This seriously deteriorates solidarity, which in turn undermines the conditions and dispositions for collective action.

Such manipulation of the subjective and discarding of the collective dimensions of work results in the progressive disappearance of empathic concern from workplaces, replaced by feelings of isolation, suspicion and anomie - which are, unsurprisingly, the ontological basis of mainstream economics. What the quantification of work is actually fostering in many workplaces is what Brons (2017) denounces as "cultural psychopathy",

\footnotetext{
5 The number of hours worked is included in customers' invoices. This is a practice that presently pervades many types of firms.
} 
namely the acceptance, or even approval, by some cultures that the individual lack of empathy (sympathy in Smith's terms) is normal rather than deviant (cultural psychopathy is different from psychopathy as an individual pathology, though both may end up being related). Brons (ibidem) emphasises that psychopathy as a cultural phenomenon might be one of the most destructive forces for mankind since it destroys community; he also notes that it may be mainstream economics' success in actually promoting ${ }^{6}$ homo economicus that is contributing to promoting cultural psychopathy. The systems of values are being transformed by current management practices; workers become obsessed with their productivity, and their perceived self-worth now also depends on the "numbers" they make. Governance by numbers infuses neo-liberal governance and values into work, the activity that takes most of individuals' time and energy. It accomplishes the "economisation of society" by extending homo economicus to all fields of society (Foucault, 2004).

The quantification and individualisation of work ultimately leads workers to perceive themselves as separated individuals rather than members of a collective, which is the condition for the mobilisation of collective resistance, as pointed out by Marx. Workers' resistance presently takes rather individual forms - organisational disaffection, cynicism, work withdrawal - but many workers end up contributing to rather than resisting the governance by numbers' practices. The workers' lack of resistance and relative disengagement from collective action worryingly signal that management practices are succeeding in spreading the individualistic values grounding neo-liberalism, which contributes to legitimise and "naturalising" them, in a vicious circle. Such legitimisation and naturalisation epitomise the de-politicisation of work. Indeed, governance by numbers deconstructs solidarities and mutual help at work. The novelty of present times is not that firms exploit workers' engagement at work - this did not appear with financialisation - but that quantification and individualisation practices are increasingly considered and accepted by workers and citizens as reasonable and justified. This generalised acceptance attests that this state of affairs is not seen as the outcome of political choices. Yet, the conception of the firm, firm governance and work organisation are highly political issues (Singer, 2019), notwithstanding Friedman's claims.

To sum up, the quantification of work (i.e. neoliberal management practices) is depriving workers of their opportunities, and hence abilities,

\footnotetext{
${ }^{6}$ This is one instance of the performativity of mainstream economics, i.e. of its capacity to make real-world economic behaviour more like its description in economic theory (Santos and Rodrigues, 2009).
} 
for cooperation - which, as developed above, involves workers' individuality, i.e. requires workers to "disclose who they are" to put it in Arendt's terms. Management rhetoric and practices, despite appealing to and using workers' individuality and subjective involvement (Lopes, 2016b), do not recognise them. To revert this, supposedly autonomous, and de facto accountable, workers should participate in the decisions that determine the goals they supposedly freely pursue.

\section{Outlining a Solution to Re-Politicise Work and the Firm}

The foregoing developments show that cooperation is at the core of the political potential of work. Work can only be a means for a positive transformation of society if an institutional environment is implemented that allows for cooperation at work. This is so because cooperation calls for deontic activity. Instituting the conditions for cooperation would establish a continuity between "work, deontic activity and democracy" (Dejours, 2009). This requires that workers have substantial control over their work, which implies that they participate in firm decision-making instances.

The arguments developed in Sections Three and Four, which highlight the influence the conception and the governance of firms have in shaping the world of work, suggest that one cannot retrieve the emancipatory potential of work without a reflection on what a firm is. The inevitable first step is therefore to build a theory of the firm. Such a theory must be consistent with what real-world firms actually are: social structures aimed at producing goods or services efficiently enough to generate profits. The firm must be understood again as a centre of production and employment rather than a bundle of assets or a nexus of contracts. Rather than (human) assets whose contribution to financial performance is to be quantified, workers must be regarded as a constitutive party of the firm. We hence follow Favereau (2018) in seeing the firm as constituted by three parties: i) shareholders, who provide capital (but are not, as referred, the owners of the firm); ${ }^{7}$ ii) the structured institutional arrangement required to carry out production, which is directed by managers; iii) workers, who supply work.

Management is in charge of organizing social and productive interdependence; it is a technical and social necessity without which no collective would function. It incorporates the collective productive purpose, i.e. the interest common to the three parties. Shareholders do not participate in

\footnotetext{
7 We are aware that the theory of the firm proposed here is a theory of corporate firms, which are but a tiny fraction of firms. However, this is the type of firms theorised in economics and, importantly, these firms' management practices are taken as benchmarks and progressively diffuse to all type of work organisations.
} 
the productive process nor do they determine or direct work organisation. Workers are subordinate not to shareholders but to the collective of production, formed by themselves and their fellow members, a collective directed by management. It is important to analytically distinguish the three parties constituting a corporate firm because each party has goals that partly conflict with those of the others. Besides, acknowledging the three parties helps clarify and better understand the experience of work.

The second step is to outline the firm governance mode that could establish, though tentatively, the conditions for cooperation and for work to fulfill its political function. Codetermination is one such governance mode; it is defined as the presence of employee representatives on boards, with the same rights as shareholders and at least one third of seats, plus the institution of work councils, composed of workers and managers, with decision rights on work organisation (Favereau, 2018).

Board-Level Employee Representation is common in Europe: in 11 countries employee representatives comprise at least $1 / 3$ of board members (7 other countries have fewer worker representatives); $36 \%$ of European workers are represented on the boards (Waddington and Conchon, 2016). But the codetermination (Mitbestimmung in Germany) mode of firm governance only exists in Germany and Scandinavian countries. In these countries, employees hold at least one third of the seats on boards, which allows them to participate in strategic decisions (relocation, offshoring, employment policy), and this representation is complemented by powerful plant-level work councils (Betriebsrat), where workers participate in operational decisions (work organisation, working conditions) with managers.

Codetermination is a mode of firm governance that institutionally recognises that work collectives are the building blocks of firms. It acknowledges that firms are constituted by three parties, which allows for placing the collective productive purpose, as opposed to shareholders' interests, at the centre of firm governance. Codetermination assumes that there is a radical conflict of interests between labour and capital, and also that this conflict generates the need to organise coexistence institutionally. The importance of workplace work councils is critical: i) experience shows that the most crucial factor for the success of employee participation is that it is not driven by top-down processes but emerges from the collectives of work, and ii) it is the level at which cooperation takes place de facto. Whilst codetermination implies a weakening of the command and control structures, it does not eliminate managerial authority. For what is needed is not the absence of power but its democratisation (Lopes, forthcoming). 
After having thoroughly studied labour movements in the period after the Second World War, Trentin (2012) concludes that it is not private ownership that prevented workers' emancipation but the "private" character of labour relations within firms. Since labour movements assumed that no emancipation is possible within capitalism, there was no real fight for workers' control over work organisation at the workplaces; ${ }^{8}$ the hope for more democratised work was relegated to a distant future and a different type of society. However, it might be argued that workplaces are arenas where the disposition for political action is effectively cultivated. For Pateman (1970), direct participation at work is an essential element of democracy to the extent that it contributes to developing the qualities needed for responsible public action - self-confidence, public-spiritedness, willingness to cooperate, which results in enhanced political participation. That is, the more control and influence individuals exercise over their work life, the better equipped and more inclined they are to participate in community life (Lopes et al., 2014; Karasek and Theorell, 1990). For Pateman, in the absence of the vital training ground of low level participation, only few workers (certainly the most educated) would take up the opportunity offered in participative governance. For "society itself is produced and reproduced along the lines of relations found at work" (Cleghorn, 2007: 307).

Codetermination, by instituting the participation of workers at both board level and workplace level would therefore definitely foster the political function of work. However, Hyman (2016) points out that the present financialised stage of capitalism undermines codetermination: strategic decision-making is increasingly removed from the sphere of codetermination, the very identity of the employer is often obscure, and competitive advantage is given priority over the workers' interests. This suggests that codetermination is an effective solution only if it is institutionally established in a sufficient number of closely related countries. In fact, during the 1970s, the Common Market country members discussed a project of European directive that would unify corporate law and generalise codetermination in European member states (Favereau, 2018). But in the 1980s, the neoliberal wave succeeded in imposing its vision of the world and of the firm, a vision that relegated codetermination to oblivion and disregard (also in

\footnotetext{
${ }^{8}$ Labour movements intensely and successfully fought for many issues, including the improvement of work conditions, but never really fought for more control of workers over work-related decisions within firms. Bargaining processes were supposed to take place between trade-unions and employers mostly outside of and at a higher level than the workplace.
} 
the academic world). Nonetheless, a very recent but pervasive interest in codetermination is now observed ${ }^{9}$ that gives some reasons for hope.

\section{Conclusion}

This paper discusses the political function of work in both theoretical and empirical terms. It begins by briefly recalling that Karl Marx saw an emancipatory potential in work for two reasons: i) work is a means for self-development and ii) wage work creates the conditions for class consciousness and consequently for the workers' fight for emancipation. Conversely, Hannah Arendt considered work and labour as a-political activities, on the grounds that there is no room in work/labour for the workers' individuality, which implies that emancipation is to be pursued through (political) action exclusively. Contra Arendt we argue that production in firms is a collective endeavour that calls for cooperation among workers. Cooperating involves entering into interpersonal interactions which activate sympathy and related "deontic activity" (Dejours, 2009), an activity that highly engages the workers' individuality.

We then defend that a comprehensive theoretical and empirical understanding of the political function of work calls for an examination not only of the concept and historical forms taken by work but also of the conception and historical forms taken by firms. We accordingly describe the (mainstream economics) agency theory of the firm, highlighting its role in the present financialisation process and how it transforms firm governance. The contemporary world of work, which is markedly shaped by firm-level financialisation processes, is then characterised by pervasive quantification and individualisation trends. These trends are embodied in a set of "governance of work by numbers" (Supiot, 2015) practices that, on the one hand, destroy the collectives of work and related solidarity and, on the other hand, make workers focus on their productivity and the individualised targets they are required to meet. We regard these two phenomena as epitomizing a profound depoliticisation of work.

If twentieth-century social philosophers renounced the belief in the emancipatory potential of work, it is now workers who are led to abandon their hope for emancipation in and through work, not because their individuality is not engaged in work but because they are led to solely concentrate on it.

\footnotetext{
${ }^{9}$ In the academic world, the British Journal of Industrial Relations recently organised a workshop to Board-Level Employee Representation, and a special issue is forthcoming. In the US, the issue is discussed in political arenas (see Holmberg, 2019).
} 
We end by outlining a solution to re-politicise work and the firm, namely through the generalisation of the codetermination governance mode, which institutes workers' participation in decisions at both board level and workplace level. This mode of firm governance recognises that work collectives are the building blocks of firms and create the conditions for workers to develop their disposition for political action. Codetermination may be a way to reestablish the formation of collectives of work and consequently rehabilitate solidarity. Solidarity, which is a major benefit of cooperation, is the political side of sympathy/empathy; it is the greatest threat to neoliberalism because when individuals prefer being together than competing against each other, neoliberalism is at risk.

Edited by Scott M. Culp

\section{References}

Alvehus, Johan; Spicer, André (2012), "Financialization as a Strategy of Workplace Control in Professional Service Firms", Critical Perspectives on Accounting, 23, 497-510.

Arendt, Hannah (1958), The Human Condition. Chicago: University of Chicago Press. Armour, John (2005), "The Proprietary Foundations of Corporate Law", ESCR Working Paper, 299. Cambridge: Center for Business Research, University of Cambridge.

Bodie, Matthew (2012), "The Post-Revolutionary Period in Corporate Law", Seattle University Law Review, 35, 1033-1059.

Bolino, Mark; Grant, Adam (2016), "The Bright Side of Being Prosocial at Work and the Dark Side too: A Review and Agenda for Research on Other-Oriented Motives, Behavior, and Impact in Organizations", The Academy of Management Annals, 1-72. Boyer, Robert (2005), "From Shareholder Value to CEO Power", PSE Working-Papers, 10. Brons, Lajos (2017), The Hegemony of Psychopathy. Santa Barbara, CA: Brainstorm Books.

Cleghorn, Stephen (2007), "Can Workplace Democracy Transform Capitalist Society? Durkheim and Burawoy Compared”, Sociological Inquiry, 57(3), 304-315.

Cukier, Alexis (2017), "Critique démocratique du travail", Tracés - Revue de Sciences Humaines, 32, 145-164.

Davis, Alyssa; Mishel, Lawrence (2014), "CEO Pay Continues to Rise as Typical Workers Are Paid Less", Economic Policy Institute. Accessed on 26.01.2019, at https://www. epi.org/publication/ceo-pay-continues-to-rise/.

Dejours, Christophe (2009), Travail vivant - Travail et émancipation. Paris: Payot.

Dejours, Christophe (2016), "Psychodynamique du travail et politique", Travailler, 36(2), 75-90. 
Dur, Robert; Non, Arjan; Roefsma, Hein (2010), "Reciprocity and Incentive Pay in the Workplace”, IZA Discussion Paper, 4782.

Favereau, Olivier (2016), The Impact of Financialisation of the Economy on Enterprises and Labour Relations. Genève: International Labour Organization.

Favereau, Olivier (2018), Rapport sur les modèles de gouvernance d'entreprise. Genève: International Labour Organization.

Favereau, Olivier, Baudoin Roger (2015), Penser l'entreprise - Nouvel horizon du politique. Paris: Collège des Bernardins.

Fischbach, Frank (2015), Le sens du social-Les puissances de la coopération. Paris: Lux Éditeurs.

Foucault, Michel (2004), Naissance de la biopolitique (Cours au Collège de France 1978-1979). Paris: Éditions Gallimard.

Friedman, Milton (1970), "The Social Responsibility of Business is to Increase Its Profit", The New York Times Magazine, $13^{\text {th }}$ September, 32-33.

Gallese, Vittorio (2008), "Empathy, Embodied Simulation and the Brain”, Journal of the American Psychoanalytic Association, 56(3), 769-781.

Goshal, Sumantra (2005), “Bad Management Theories Are Destroying Good Management Practices”, Academy of Management Learning and Education, 4(1), 75-91.

Hodgson, Geoffrey M. (2013), From Pleasure Machines to Moral Communities. Chicago: The University of Chicago Press.

Holmberg, Susan R. (2019), "Workers on Corporate Boards? Germany's Had Them for Decades", The New York Times, 6 ${ }^{\text {th }}$ January. Accessed on 26.01.2019, at https://www.nytimes.com/2019/01/06/opinion/warren-workers-boards.html?em_ pos=small\&emc=edit_ty_20190107\&nl=opinion-today\&nl_art=0\&nlid=65653411 emc\%3Dedit_ty_20190107\&ref=headline\&te=1.

Honneth, Axel (1982), "Work and Instrumental Action: On the Normative Basis of Critical Theory”, Thesis Eleven, 5(6), 162-184.

Hyman, Richard (2016), “The Very Idea of Democracy at Work”, Transfer, 22(1), 11-24. Jensen, Michael; Meckling, William (1976), "Theory of the Firm: Managerial Behavior, Agency Costs and Ownership Structure”, Journal of Financial Economics, 3(4), 305-360.

Karasek, Robert; Theorel, Tores (1990), Healthy Work: Stress, Productivity and the Reconstruction of Working. New York: Basic Books.

Lopes, Helena (2016a), “The Political and Public Dimensions of Work”, The Journal of Australian Political Economy, 76, 5-28.

Lopes, Helena (2016b), “Agency Theory and Social Interactions at Work”, Review of Social Economy, 74(4), 349-358.

Lopes, Helena (forthcoming), “Taking Authority Seriously - Institutional Implications”, Journal of Economic Issues. 
Lopes, Helena; Calapez, Teresa; Lagoa, Sérgio (2014), “Declining Autonomy at Work in the EU and Its Effect on Civic Behaviour", Economic and Industrial Democracy, 35(2), 341-366.

Marx, Karl (1909), Capital: Critique of Political Economy. Volume I: The Process of Capitalist Production. Chicago: Charles H. Kerr and Co. Translation by Samuel Moore and Edward Aveling [orig. 1867]. Accessed on 04.01.2019, at https://oll. libertyfund.org/titles/marx-capital-a-critique-of-political-economy-volume-i-the-process-of-capitalist-production.

Non, Arjan (2012), “Gift-Exchange, Incentives and Heterogeneous Workers”, Games and Economic Behaviour, 75(1), 319-336.

Pateman, Carole (1970), Participation and Democratic Theory. Cambridge: Cambridge University Press.

Rizzolatti, Giacomo; Craighero, Laila (2005), “Mirror Neuron: A Neurological Approach to Empathy", in Jean-Pierre Changeux; Antonio R. Damasio; Wolf Singer; Yves Christen (eds.), Neurobiology of Human Values. Berlin: Springer-Verlag, 107-123.

Robé, Jean-Philippe (2012), "Being Done with Milton Friedman”, Accounting, Economics and Law, 2(2). DOI: 10.1515/2152-2820.1047

Santos, Ana; Rodrigues, João (2009), "Economics as Social Engineering? Questioning the Performativity Thesis", Cambridge Journal of Economics, 33, 985-1000.

Singer, Abraham (2019), The Form of the Firm. Oxford: Oxford University Press.

Smith, Adam (2017), The Theory of Moral Sentiments. Edinburgh: Andrew Millar [orig. 1759]. Accessed on 18.09.2018, at https://www.earlymoderntexts.com/assets/ pdfs/smith1759.pdf.

Sugden, Robert (2005), "Fellow-Feeling”, in Benedetto Gui; Robert Sugden (eds.), Economics and Social Interactions. Cambridge: Cambridge University Press, 52-75.

Supiot, Alain (2015), La gouvernance par les nombres. Nantes: Éditions Fayard.

Trentin, Bruno (2012), La cité du travail. Paris: Éditions Fayard.

Waddington, Jeremy; Conchon, Aline (2016), Board-Level Employee Representation in Europe. New York: Routledge.

Zak, Paul; Barraza, Jorge (2013), “The Neurobiology of Collective Action”, Frontiers in Neuroscience, 7, 1-9.

Zamagni, Stefano (2018), "Le bien commun dans le discours économique actuel”, Transversalités, 144(1), 7-33. 
Received on 12.02.2019

Accepted for publication on 10.06.2019

\author{
Helena Lopes \\ ISCTE - Instituto Universitário de Lisboa | DINÂMIA'CET-IUL - Centro de Estudos sobre a \\ Mudança Socioeconómica e o Território do ISCTE-IUL \\ Avenida das Forças Armadas, 1649-026 Lisboa, Portugal \\ Contact: helena.lopes@iscte-iul.pt \\ ORCID: http://orcid.org/0000-0003-1710-778X
}

\section{A (Des) Politização do Trabalho - Um Inquérito à Função Política do Trabalho}

Este artigo revisita o debate sobre a função política do trabalho, definido como o contributo do trabalho para a produção e transformação de relações sociais, tanto em termos conceituais como em termos empíricos. Inicia-se com um breve relance dos termos do debate sobre o potencial emancipatório do trabalho, conforme perspetivado por Karl Marx e Hannah Arendt, argumentando de seguida, contra Arendt que, como o trabalho é uma atividade coletiva e cooperativa, ele não é apolítico. O principal contributo do artigo consiste em discutir a questão através de uma abordagem crítica da literatura sobre as teorias económicas da empresa e sobre a economia do trabalho, duas vertentes da literatura geralmente mantidas separadas. Consideramos as tendências de quantificação e individualização que caracterizam o mundo do trabalho contemporâneo como um processo de despolitização, processo ligado à teoria da agência, uma teoria da empresa que legitima a financiarização. Concluímos delineando uma forma de repolitizar o trabalho e a empresa.

Palavras-chave: gestão empresarial; politização; relações sociais; salário; trabalho.

\section{La (dé)politisation du travail - Une enquête sur la fonction politique du travail}

Cet article revisite le débat sur la fonction politique du travail, définie comme une contribution du travail à la production et à la transformation de rapports sociaux, débat mené tant en termes conceptuels qu'en termes empiriques. Nous commençons par brièvement rappeler les termes du débat sur le potentiel émancipatoire du travail, selon Karl Marx, potentiel que Hannah Arendt dénie. Contra Arendt, nous soutenons que, comme le travail est une activité collective et coopérative, il n'est pas apolitique. La principale contribution de cet article est de débattre cette question à travers une approche critique de la littérature sur les théories économiques de l'entreprise et sur l'économie du travail, deux volets généralement maintenus séparés dans la littérature économique. Les tendances de quantification et d'individualisation qui caractérisent le monde du travail contemporain constituent, selon nous, un processus de dépolitisation, processus lié à la théorie de l'agence de l'entreprise qui légitime la financiarisation. En guise de conclusion, nous traçons les pourtours de ce qui pourrait être une façon de repolitiser le travail et l'entreprise.

Mots-clés: gestion d'entreprise; politisation; relations sociales; salaire; travail. 
